\title{
Composition, structure, and intra-stand spatial patterns along a disturbance severity gradient in a Quercus stand
}

\author{
Lauren E. Cox ${ }^{1, *}$, Justin L. Hart ${ }^{1}$, Daniel C. Dey ${ }^{2}$, and Callie J. Schweitzer ${ }^{3}$ \\ ${ }^{1}$ Department of Geography, University of Alabama, Tuscaloosa, Alabama 35487 \\ ${ }^{2}$ Northern Research Station, USDA Forest Service, Columbia, Missouri 65211 \\ ${ }^{3}$ Southern Research Station, USDA Forest Service, Huntsville, Alabama 35801 \\ * Author for correspondence: L.E. Cox, lecox@ crimson.ua.edu, +1 2053481673
}

\begin{abstract}
Natural forest disturbances, which drive succession and development, differ in extent, severity, and return interval and range from frequent, gap-scale disturbances, to infrequent standreplacing events. Most studies have focused on natural disturbances near the ends of the disturbance severity gradient and relatively little quantitative information is available on intermediate-severity disturbance. On 20 April 2011, an EF1 tornado tracked $5 \mathrm{~km}$ through the Sipsey Wilderness in Alabama and resulted in a patchwork mosaic of disturbed areas. To analyze the effects of the intermediate-severity wind event on composition, structure, and intra-stand spatial patterns, we established a $100 \times 200 \mathrm{~m}(2 \mathrm{ha})$ rectangular plot perpendicular to the path of the storm within an affected Quercus alba stand. Based on the basal area removed (i.e. basal area of snags, snapped stems, or uprooted stems in decay class 1) by the wind event, we divided the plot into disturbance classes (minimal, light, and moderate) to compare compositional and structural attributes along a disturbance severity gradient. Composition varied little across the
\end{abstract}


disturbance gradient, but diversity was highest in the moderately disturbed neighborhoods. Stems were relatively intermingled by species (i.e. each tree neighbored by trees of different species) in each disturbance severity class. However, some species, such as Fagus grandifolia and Ostrya virginiana exhibited less intermingling than Quercus spp. and stems class in the "other spp." taxonomic group. Large stems were disproportionately removed by the storm in the light and moderate disturbance categories. In the light disturbance class, $O$. virginiana was significantly less likely to experience mortality from the storm, which may in part explain the relatively high density of $O$. virginiana stems in the plot.

Keywords: canopy disturbance, Quercus (oak), stand development, succession

\section{Introduction}

Forest disturbances alter species composition and stand structure and thus, direct successional and developmental pathways (Lorimer 1980, White et al. 1985, Foster et al. 1998, White and Jentsch 2001). Discrete forest disturbances are often classified by their spatial extent and severity, and range from localized, gap-scale events to stand-wide, catastrophic events (Oliver and Larson 1996). Along this disturbance severity gradient, intermediate disturbances are those larger in extent than gap-scale disturbances and smaller than catastrophic events (Hanson and Lorimer 2007, Cowden et al. 2014, White et al. 2015). An inverse relationship exists between the intensity (e.g. wind speed) and the return interval of a disturbance (Frelich and Lorimer 1991, Mitchell 2013). Stand-wide disturbances (defined here as $25 \%$ of canopy trees affected) occur every 30 to 50 years in the Central Hardwood Forest of the USA (Nowacki and Abrams 1997, Ruffner and Abrams 1998, Hart et al. 2012). Although the return interval of 
intermediate-severity disturbances in this region is shorter than the life of canopy trees (100-400 years; Lorimer 1989, 2001, Stueve et al. 2011, Di Filippo et al. 2015), the vast majority of research on natural canopy disturbance has focused on either catastrophic or small gap-scale disturbances (Seymour et al. 2002). As such, relatively little quantitative information is available on natural intermediate forest disturbance processes.

The intermediate disturbance category of the disturbance gradient encompasses events that span a large range of severities and spatial patterns of tree mortality. For example, an intermediate-severity disturbance may remove canopy trees through a stand in a manner resembling many simultaneous gap-scale disturbances, or remove all canopy trees in a neighborhood (e.g. 0.001-0.1 ha; Frelich et al. 1998), but not affect the remainder of the stand. Natural intermediate-severity disturbance agents include windstorms, mixed severity fires, pathogens, and insect outbreaks among others (Oliver and Larson 1996). Agents of intermediateseverity disturbance may result in size-specific or species-specific tree mortality (Everham and Brokaw 1996, Canham et al. 2001, Peterson 2007, White et al. 2015) and thus, cause unique spatial patterns of residual trees and biological legacies. For example, large trees, because of their relatively large canopy volumes, are disproportionately removed by strong wind events (Foster and Boose 1992, Peterson and Rebertus 1997, Peterson 2007, Rich et al. 2007), whereas trees with relatively thin bark, to some degree a function of tree size, are most susceptible to mortality from fire (Regelbrugge and Smith 1994, Brose et al. 2013) The variation amongst disturbance agent, severity, and spatial pattern of both killed and residual stems necessitates quantitative descriptions of different intermediate-severity disturbances to project subsequent successional and developmental trajectories.

The overarching goal of this study is to describe the effects of an intermediate-severity 
wind event on the composition, structure, and intra-stand spatial patterns of trees along a canopy disturbance severity gradient. Specifically, we aimed to 1) quantify the effects of an intermediate-severity wind disturbance on composition among neighborhoods of increasing disturbance severity, 2) describe the effects on stand structure among neighborhoods, 3) analyze the effects of an intermediate-severity disturbance on compositional diversity and species intermingling, and 4) investigate stem mortality trends based on size and species. Based on our preliminary observations and literature review, we hypothesized the wind disturbance disproportionately removed larger canopy trees and that the frequency of tree mortality was greatest near the center of the tornado track and decreased with increased distance from the path. Furthermore, we hypothesized species diversity and intermingling would be highest in areas where mortality was greatest and that these measures would decrease along the canopy disturbance severity gradient. Our findings provide information on tree mortality patterns and the biological legacies left by an intermediate-severity disturbance and may be used to guide natural disturbance-based silvicultural systems.

\section{Methods}

\subsection{Study area}

The Sipsey Wilderness, a 10,085 ha reserve established in 1975, is located in the William B. Bankhead National Forest in Lawrence and Winston Counties, Alabama, USA. The reserve is situated on the Cumberland Plateau section of the Appalachian Plateaus physiographic province (Fenneman 1938). The area is located within the Dissected Plateau ecoregion (level IV) of the Southwestern Appalachians (level III) ecoregion (Griffith et al. 2001). The topography of the region is complex, characterized by steeps slopes and narrow ridges and valleys, no longer 
resembling a true plateau (Smalley 1979). The geology is primarily composed of the Pennsylvania Pottsville formation, which consists of quartzose sandstone with discontinuous layers of limestone, siltstone, and coal (Szabo 1988). Soils in the region are typically shallow, acidic, and well drained (USDA 1959). The regional climate is classified as humid mesothermal with short, mild winters and long, hot summers (Thornthwaite 1948). Mean annual temperature is $16^{\circ} \mathrm{C}$ with monthly means of $5^{\circ} \mathrm{C}$ and $26^{\circ} \mathrm{C}$ for January and July, respectively. The average growing season is 220 days and spans from late-March to early-November (Smalley 1979). Average annual precipitation is $1380 \mathrm{~mm}$ with monthly means of $138 \mathrm{~mm}$ and $113 \mathrm{~mm}$ for January and July, respectively (PRISM Climate Group 2015).

Braun (1950) classified this portion of the Cumberland Plateau as a transition zone between the Mixed Mesophytic Forest Region to the north and the Quercus-Pinus Forest Region to the south. Plant community composition in this area is largely influenced by topography (Zhang et al. 1999) and soil-water availability (Hinkle 1989, Clatterbuck et al. 2006). Quercus spp. were included in most community types and Quercus was the most abundant genus of the 14 ecological community types identified by Zhang et al. (1999) in the Sipsey Wilderness. These community types ranged from Pinus virginiana-dominated xeric sites to Fagus grandifolia and Acer saccharum-dominated mesic sites. Environmental gradients in this region are steep and species composition may change abruptly with relatively minor changes in slope position. (Zhang et al. 1999, Parker and Hart 2014).

On 20 April 2011, an EF1 tornado embedded within a bow-echo affected the William B. Bankhead National Forest and multiple stands within portions of the Sipsey Wilderness, creating a mosaic of disturbed areas. The tornado produced winds up to $153 \mathrm{kph}$, accompanied by straight-line winds with speeds up to $145 \mathrm{kph}$ (NWS 2011). Areas of highest disturbance severity 
were concentrated in the tornado path and severity decreased with distance from center of the path, creating a canopy disturbance severity gradient.

\subsection{Field methods}

All field data were collected during the fourth growing season post-disturbance. Using a shapefile of Forest Service stand delineations and aerial photography in ArcMap v. 10.2 as reference, we selected a 182 ha Quercus alba stand that was contained completely within the Sipsey Wilderness, had no written records of previous broad-scale disturbances, and was partially disturbed by the 20 April 2011 EF1 tornado. Within this stand, we established a 2 ha $(100 \times 200 \mathrm{~m})$ permanent, rectangular plot. The plot captured a gradient of disturbance, from severe disturbance at the center of the tornado path to neighborhoods of the stand that were seemingly unaffected by the wind event, based on visual reconnaissance. Elevation varied by 37 $\mathrm{m}$ within the plot and the contours were oriented perpendicular to the path of the 2011 storm so effects of wind disturbance were not confounded by topography. The plot was situated at least 25 $\mathrm{m}$ from the stand boundary to eliminate edge effects. A $5 \times 5 \mathrm{~m}$ grid was superimposed over the 2 ha plot to divide the plot into disturbance severity subplots after sampling.

Within each $5 \times 5 \mathrm{~m}$ quadrat, all live stems $\geq 5 \mathrm{~cm}$ diameter at breast height $(1.4 \mathrm{~m}$ above the surface, $\mathrm{DBH}$ ) were recorded for species, $\mathrm{DBH}$ and crown class to record stand characteristics. Crown class was based on the amount of intercepted light and included overtopped, intermediate, codominant, and dominant stems (Oliver and Larson 1996). We also noted whether the crown was visually damaged or undamaged (i.e., major branches removed, etc.). For all dead, woody stems $\geq 5 \mathrm{~cm}$ rooted within each quadrat, we identified the stem to the lowest taxonomic level possible, recorded the DBH and decay class, and classified each stem by 
mode of death. DBH was recorded at $1.4 \mathrm{~m}$ above the root collar, where the estimated standing DBH would have been measured. Decay classes assigned to each dead stem include: decay class 1 (least decayed, sound wood, intact bark, branches present), decay class 2 (sound to somewhat rotten wood, bark may be intact, branch stubs firmly attached), decay class 3 (substantially rotten wood, bark slippage, branch stubs easily pulled from softwood species, wood texture is soft and compacts when wet), or decay class 4 (most decayed, mostly rotten wood, branch stubs rotted down to log surface, bark no longer attached or absent, log is oval or flattened in shape; Fraver et al. 2002). Modes of death included uprooted stem (overturned with root network uplifted), snapped stem (broken above ground and below crown), and snag (standing dead tree with crown mostly intact; Clinton et al. 1993, Hart and Grissino-Mayer 2009, Richards and Hart 2011). We recorded the location of every stem, both living and dead, within each $5 \times 5 \mathrm{~m}$ quadrat by recording the distance and azimuth from the northwest corner of the quadrat.

\subsection{Analytical methods}

To analyze the effects of the intermediate-severity wind event, we assumed that stems classified as decay class 1 were those impacted by the storm and those resulting from background mortality shortly prior to and since the wind event (Cowden et al. 2014, White et al. 2015). We used percent background mortality from studies in adjacent stands $\left(1.2 \% \mathrm{~m}^{2} \mathrm{ha}^{-1}\right.$ removed) to approximate background mortality and estimate the actual basal area removed by the 2011 wind event (Runkle 1982, Cowden et al. 2014, White et al. 2015). However, because of the spatially explicit field sampling and data analysis, we did not differentiate between stormkilled decay class 1 stems and decay class 1 stems as a result of background mortality in data analyses. 
We divided the plot into three disturbance severity categories (minimal, light, and moderate disturbance classes) to compare differences in stand composition and structure among neighborhoods of increasing disturbance severity. To determine boundaries of disturbance severity classes, we used simple kriging with a normal score transform of basal area of decay class 1 stems for $20 \times 20 \mathrm{~m}$ quadrats within the 2 ha plot. This spatial scale corresponded to the approximate crown diameter of dominant $Q$. alba stems in the stand and was broad enough to determine general trends of basal area removed and remain unbiased by highly localized areas of disturbance (Johnson et al. 2009, Zenner et al. 2015). Using contours created by the simple kriging, we defined disturbance severity class boundaries by following the borders of $5 \mathrm{~m} \times 5 \mathrm{~m}$ quadrat boundaries through the 2 ha plot (see plot establishment description). The minimum and maximum contour values were $0.0-2.3 \mathrm{~m}^{2} \mathrm{ha}^{-1}(0-8 \%$ basal area removed) for minimal disturbance, 2.3-6.4 $\mathrm{m}^{2} \mathrm{ha}^{-1}$ (8-24\% basal area removed) for light disturbance, and 6.4-20.0 $\mathrm{m}^{2}$ $\mathrm{ha}^{-1}(24-75 \%$ basal area removed) for moderate disturbance (Fig. 1). These contour values related to percentages of basal area removed of disturbance classes in Hanson and Lorimer (2007). The minimal, light, and moderate disturbance classes were $0.570,0.855$, and 0.575 ha in size, respectively, and therefore were composed of multiple $0.001-0.1$ ha neighborhoods.

We calculated density, relative density, dominance (basal area $\left.\left(\mathrm{m}^{2} \mathrm{ha}^{-1}\right)\right)$, and relative dominance by species for each disturbance severity class to compare effects of the disturbance on composition and structure. Values were calculated for both living and decay class 1 stems. To analyze additional compositional patterns, trees were divided into the following taxonomic groups: Acer-Fagus, Quercus-Carya, Ostrya virginiana, and other species. Taxonomic groups were chosen based on taxa dominance across all disturbance severity classes. We included Acer and Fagus in one taxonomic group and Quercus and Carya in a single taxonomic group based on 
shade tolerance and successional trends in the Central Hardwood Forest Region (e.g. Rentch et al. 2003, Cowden et al. 2014). Trees within each taxonomic group were divided into $5 \mathrm{~cm}$ size bins and diameter distributions were created for each group (Nyland 2002). Diameter distribution shapes were assigned to each taxonomic group by disturbance class following Leak (1996) and Janowiak et al. (2008). Using ordinary least squares regression, we regressed the $\log _{10}(($ stems ha$\left.{ }^{1}\right)+1$ ) of each DBH size class bin by all combinations of the corresponding DBH size class midpoint (DBH), $\mathrm{DBH}^{2}$, and $\mathrm{DBH}^{3}$ (Janowiak et al. 2008, Keyser and Loftis 2012). The model used to determine the diameter distribution shape to each group was chosen by the highest adjusted $R^{2}$ value and the lowest root mean square error. We assigned the diameter distribution shape according to the sign (positive or negative) of significant $\mathrm{DBH}, \mathrm{DBH}^{2}$, and $\mathrm{DBH}^{3}$ coefficients ( $p<0.05)$, following Janowiak et al. (2008). To analyze size distributions of $O$. virginiana which had little differentiation among stem size, we created diameter distributions using $1 \mathrm{~cm} \mathrm{DBH}$ size classes for each disturbance severity class. We did not assign shapes to the O. virginiana diameter distribution curves using polynomial regression.

To describe the distribution of stem size, we calculated the Gini coefficient $(G C)$ for each taxonomic group and disturbance class (Gini 1912). This index was originally developed to describe inequities in income among populations and has since been applied to describe the inequality of plant sizes (Weiner and Solbrig 1984). Lexerød and Eid (2006) determined that the $G C$ most clearly differentiated between diameter distributions compared to multiple indices. Values for the $G C$ range between 0 and 1; a value of 0 indicated that all stems had the same DBH, whereas a value of 1 indicated that all stems had dissimilar DBH (Lexerød and Eid 2006). To demonstrate the impact of $O$. virginiana on the diameter distribution for other species, the $G C$ 
for other species was calculated three ways: other species including $O$. virginiana, $O$. virginiana alone, and other species excluding $O$. virginiana.

To describe the compositional diversity of trees and compare these measures to analogous studies, we calculated Shannon diversity $\left(H^{\prime}\right)$ and evenness $(J)$ for each disturbance class. Using the "vegan" package in R (Oksanen et al. 2016), we also calculated randomized species accumulation curves for each disturbance severity class to account for differences in sample size (Gotelli and Colwell 2001). We calculated the Mingling index $\left(M_{i}\right)$ to determine the degree of species intermingling (Pommerening 2002). The $M_{i}$ describes the level of interspersion of species within a stand based on the species of the four nearest neighbors of each tree (Pommerening 2002, Kint et al. 2003, Saunders and Wagner 2008, Pastorella and Paletto 2013). The $M_{i}$ is calculated for each tree within a group or stand and values range from 0 to 1 ( 0 for trees with all nearest neighbors of the same species; 1 for trees with no nearest neighbors of the same species). Stand $M_{i}$ values are calculated by averaging tree $M_{i}$ values. We also analyzed $M_{i}$ values by species to determine species-specific variation in interspersion. For species-specific $M_{i}$ values, low values indicate that stems of the focal species are more likely to occur in spatial groups (neighborhoods of 5 stems), whereas high values indicate that stems of the focal species tend to occur alone (i.e. interspersed with other species). In addition, we created histograms of $M_{i}$ for each taxonomic group for the entire 2 ha plot regardless of disturbance class. For stand averages of the $M_{i}$, low values may indicate low species diversity or a clumping of species within a stand, whereas high values may indicate high species diversity or a highly interspersed distribution of species (Graz 2004). For calculations of the $M_{i}$, we used a $5 \mathrm{~m}$ buffer edge correction within each irregularly shaped disturbance severity class to reduce edge-bias. (Pommerening and Stoyan, 2006). 
To determine species- and size-specific mortality trends, we used multiple logistic regression analysis with tree mortality (live v. decay class 1) as the dependent variable and DBH and taxonomic groups (coded as dummy variables) as independent variables (Trexler and Travis 1993, Hanson and Lorimer 2007, Peterson 2007). We applied the Box-Tidwell transformation to verify the logit-transformation of tree mortality exhibited a linear relationship with $\mathrm{DBH}$, the only continuous predictor variable (Menard 1995). Four multiple logistic regressions for tree mortality were conducted: one for all stems in the 2 ha plot, and one for stems in each disturbance severity class. Each model was built using the forward variable selection method with an entry threshold of $p<0.05$ (Peterson 2007). We used the likelihood ratio $\chi^{2}$ to test the significance of each model and the Wald $\chi^{2}$ test to evaluate the significance of variables within the model (Trexler and Travis 1993, Hosmer and Lemeshow 2000, Peterson 2007). All statistical analyses were performed in SAS v.9.3 and all spatial analyses were performed in ArcMap v. 10.2 and R using the "spatstat package" (Baddeley and Turner, 2005).

\section{Results}

\subsection{Effects on composition and structure}

Live basal area for the minimal, light, and moderate disturbance severity classes was 23.5 $\mathrm{m}^{2} \mathrm{ha}^{-1}, 23.2 \mathrm{~m}^{2} \mathrm{ha}^{-1}$, and $13.7 \mathrm{~m}^{2} \mathrm{ha}^{-1}$, respectively. Basal area of decay class 1 stems (i.e. background mortality + killed by wind event) was $2.1 \mathrm{~m}^{2} \mathrm{ha}^{-1}$ for the minimal disturbance class, $5.1 \mathrm{~m}^{2} \mathrm{ha}^{-1}$ for the light disturbance class, and $11.0 \mathrm{~m}^{2} \mathrm{ha}^{-1}$ for the moderate disturbance class. We estimated that the 2011 wind event removed $1.8 \mathrm{~m}^{2} \mathrm{ha}^{-1}(7 \%), 4.7 \mathrm{~m}^{2} \mathrm{ha}^{-1}(17 \%)$, and $10.7 \mathrm{~m}^{2} \mathrm{ha}^{-1}$ (43\%) in the minimal, light, and moderate disturbance classes, respectively. In all disturbance classes, $Q$. alba was the most dominant tree species and $O$. virginiana occurred at the highest 
density (Table 1). In the minimal disturbance class, F. grandifolia (14\%) and A. saccharum (8\%) were the second and third most dominant species, and F. grandifolia (19\%) and Q. alba (17\%) occurred second and third most abundantly. In the light disturbance class, $O$. virginiana (7\%) and $F$. grandifolia (4\%) were the second and third most dominant species, and Q. alba (18\%) and $C$. florida (7\%) occurred second and third most abundantly. In the moderate disturbance class, O. virginiana (11\%) and A. saccharum (7\%) were the second and third most dominant species, and A. saccharum (15\%) and Q. alba (11\%) occurred second and third most abundantly.

Among decay class 1 stems, the most dominant species in the minimal, light, and moderate disturbance classes was $Q$. alba. Quercus alba also had the highest density of decay class 1 stems in the minimal and light disturbance categories, whereas $O$. virginiana was the most abundant species of decay class 1 stems in the moderate disturbance class (Table 2). Carya ovata and L. tulipifera were the second and third most dominant species of decay class 1 stems in the minimal disturbance class, and $O$. virginiana had the second highest density in the minimal disturbance class for decay class 1 stems. In the light disturbance class for decay class 1 stems, C. tomentosa and P. echinata were the second and third most dominant species, whereas $J$. virginiana and $O$. virginiana were the second and third most commonly occurring species. In the moderate disturbance class, $C$. ovata and $Q$. rubra were the second and third most dominant decay class 1 stems whereas Q. alba, C. glabra, and A. saccharum were the second and third most commonly occurring decay class 1 stems.

Mean DBH for all live stems was $15 \mathrm{~cm}$ whereas mean DBH for decay class 1 stems was $23 \mathrm{~cm}$ DBH. Mean DBH for live stems was $14 \mathrm{~cm}, 31 \mathrm{~cm}, 8 \mathrm{~cm}$, and $12 \mathrm{~cm}$ for the Acer-Fagus, Quercus-Carya, O. virginiana, and other spp. taxonomic groups, respectively. Mean DBH for decay class 1 stems was $15 \mathrm{~cm}, 36 \mathrm{~cm}, 10 \mathrm{~cm}$, and $18 \mathrm{~cm}$ for Acer-Fagus, Quercus-Carya, 
Ostrya virginiana, and other spp. groups, respectively. Diameter distribution shapes varied among taxonomic groups and disturbance class (Fig. 2). Acer-Fagus exhibited a concave shape in the minimal disturbance class, a negative exponential distribution in the light disturbance class, and a rotated sigmoid shape in the moderate disturbance class. Quercus-Carya stems exhibited a unimodal distribution across all disturbance severity classes. Other species were assigned a rotated sigmoid diameter distribution across all disturbance classes. For diameter distributions of $O$. virginiana stems using $1 \mathrm{~cm}$ diameter bins, the majority of stems in the minimal and light disturbance classes ranged from 5-7 cm DBH (Fig 3). In the moderate disturbance class, 52 O. virginiana stems ha ${ }^{-1} \geq 12 \mathrm{~cm} \mathrm{DBH} \mathrm{(eight} O$. virginiana stems ha ${ }^{-1} \geq 15$ cm DBH) were present, whereas in the light disturbance class nine $O$. virginiana stems ha ${ }^{-1} \geq 12$ $\mathrm{cm}$ DBH were present. No $O$. virginiana stems $\geq 12 \mathrm{~cm}$ occurred in the minimal disturbance class.

$G C$ values for Quercus were $0.29,0.40$, and 0.44 for minimal, light, and moderate disturbance classes, respectively, which are lower than overall disturbance class $G C$ values of 0.68, 0.73, and 0.69 (Fig. 2). $G C$ for $O$. virginiana was $0.25,0.31$, and 0.37 , for minimal, light, and moderate disturbance classes. The $G C$ values for the other species category, excluding $O$. virginiana, were $0.65,0.74$, and 0.74 , for minimal, light, and moderate disturbance classes.

Proportions of decay class 1 stems in $5 \mathrm{~cm}$ size classes indicated the removal of large Quercus stems. Taxa of small stems (5-25 cm DBH) in decay class 1 across all disturbance classes included in the "other species" category were J. virginiana, O. virginiana, Magnolia spp., C. florida, Fraxinus spp., P. serotina, C. caroliniana, N. sylvatica, T. americana, C. canadensis, and Ulmus spp. Taxa of large stems (> $25 \mathrm{~cm}$ ) of "other species" in decay class 1 included $L$. tulipifera, P. echinata, Ulmus spp, Fraxinus spp., and J. nigra. Stems of J. nigra only occurred 
in decay class 1 in the moderate disturbance class. Generally, the highest proportions of decay class 1 stems of Acer-Fagus occurred in 5-30 cm size classes, Carya spp. in 30-50 cm size classes, and Quercus stems from 50-75 cm size classes.

\subsection{Effects on diversity and species intermingling}

We documented 36 unique species of both live and decay class 1 stems $\geq 5 \mathrm{~cm} \mathrm{DBH}$. Both $H^{\prime}$ and $J$ were highest in the moderate disturbance class $\left(H^{\prime}=2.0, J=0.63\right)$ and lowest in the light disturbance class $\left(H^{\prime}=1.6, J=0.55\right)$. Based on randomized species accumulation curves, species richness was highest for the minimal disturbance class, followed by the moderate and light disturbance severity classes, respectively. Species accumulated the most rapidly in the moderate severity class, followed by the minimal and light severity classes (Fig 4). $M_{i}$ values of live and decay class 1 stems (i.e. pre-disturbance conditions) were $0.75,0.73$, and 0.77 for minimal, light, and moderate disturbance classes, respectively. $M_{i}$ values for live stems were $0.75,0.69$, and 0.75 , which were lower than pre-disturbance values for the light and moderate disturbance classes. The $M_{i}$ value for Carya (0.94), Acer (0.84), Quercus (0.83) and species classed in the others category (0.88) were relatively high (Fig. 5). Ostrya virginiana had a relatively low $M_{i}$ value $(0.52)$.

\subsection{Mortality related to species and size}

Across all disturbance categories, larger tree diameter classes exhibited higher proportions of basal area removed than smaller diameter classes (Fig. 6). Results from the tree mortality logistic regression for all stems in the 2 ha plot revealed DBH was the only significant main effect $\left(\chi^{2}\right.$ wald $\left.=58.6, p<0.0001\right)$. The coefficient for diameter was positive, indicating an 
increased probability of mortality with increased tree diameter. For stems in the minimal disturbance class, logistic regression did not indicate any significant effects associated with stem mortality. In the light disturbance class, DBH and $O$. virginiana were the significant main effects $\left(\chi^{2}\right.$ wald $=7.4, p=0.006 ; \chi^{2}$ wald $\left.=14.0, p=0.0002\right)$. The coefficient for $O$. virginiana was negative, indicating a decreased probability of mortality for O. virginiana stems. Conversely, the coefficient for DBH was positive. In the moderate disturbance class, DBH was the only significant effect $\left(\chi^{2}\right.$ wald $\left.=32.9, p<0.0001\right)$ and had a positive coefficient.

In all disturbance classes, snapped stems represented the most common mode of death for decay class 1 stems (57\% in minimal, 55\% in light, $47 \%$ in moderate disturbance). In light and moderate disturbance classes, stem uprooting was a more common mode of death for decay class I stems $(30 \%, 42 \%$, respectively) than snags $(15 \%, 11 \%$, respectively). Conversely, in the minimal disturbance class, snags (29\%) were more common than uprooted trees. Quercus spp. stems were the most common snags in all disturbance classes. In the moderate disturbance class, more O. virginiana and stems of the "other species" group were uprooted than snapped (Fig.7). 


\section{Discussion}

\subsection{Effects on composition and structure}

Although the return interval of intermediate-severity disturbances is shorter than the lifespan of most temperate forest species, data on the effects of such disturbances is lacking (Foster and Boose 1992, Seymour et al. 2002, Stueve et al. 2011). Four growing seasons after an intermediate-severity wind event in an upland $Q$. alba stand, species composition remained similar across disturbance severity neighborhoods. In the light and moderate severity classes, Acer spp. and Fagus spp. did not exhibit higher relative density or dominance than in the minimal disturbance class. However, the diameter distributions for Acer-Fagus in all disturbance classes indicated that these taxa were regenerating as they had relatively large densities of stems in small size classes. Conversely, the unimodal diameter distributions for Quercus stems in all disturbance classes indicated that Quercus stems were less likely to maintain dominance and more shade tolerant stems may gain dominance as larger Quercus stems senesce. The shape of Carya diameter distributions indicated some tree establishment, but at a relatively low rate compared to Acer-Fagus. Although Quercus maintained dominance after the wind disturbance, the removal of large Quercus stems in conjunction with the lack of small Quercus stems in the understory has hastened the Quercus to Acer transition (i.e. disturbance-mediated accelerated succession); a shift that is prevalent in Quercus stands throughout the Central Hardwood Forest Region (Lorimer 1984, Abrams and Scott 1989, Abrams 2005, Fei et al. 2011, Holzmueller et al. 2012).

Density of $O$. virginiana stems was greater in the light and moderate disturbance classes than in the minimal disturbance class. Total stem density in the light disturbance 
class was higher than in the minimal disturbance class and we attributed this largely to the abundance of $O$. virginiana. The largest $O$. virginiana trees were located in the moderate disturbance class neighborhood and stem size generally decreased with decreasing disturbance severity. These large stems were likely the oldest in the plot and may have served as a seed source that populated smaller size classes in the minimally and lightly disturbed neighborhoods, as $O$. virginiana are prolific seeders and produce seeds that are lightweight and easily dispersed. Thus, the pre-disturbance presence of $O$. virginiana stems may be reflected in post-disturbance results. Batista and Platt (2003) classified $O$. virginiana as a 'usurper' species, which are relatively undamaged by wind disturbance and respond with increased growth after the disturbance, as described by Bellingham et al. (1995). Batista and Platt (2003) found that O. virginiana had significantly more saplings present post-disturbance than pre-disturbance (see Keasberry et al. 2015) and that the mean radial growth rate of $O$. virginiana was significantly higher after hurricane disturbance than prior to disturbance. Similarly, Kwit and Platt (2003) found that relative growth rates of $O$. virginiana increased after the occurrence of a hurricane and growth peaked four years after disturbance. The tendency of $O$. virginiana to respond positively to disturbance in both recruitment and diameter growth in conjunction with a low probability of mortality from strong wind events because of its relatively small stature may explain the higher density of $O$. virginiana stems $\geq 5 \mathrm{~cm}$ DBH in the light disturbance class.

\subsection{Effects on diversity and species intermingling}


Although measures of diversity were relatively similar across disturbance severity classes, values for $H^{\prime}$ and $J$ were consistently highest for the moderate disturbance class and lowest for the light disturbance class neighborhoods. Species accumulation curves revealed that species richness was slightly higher in the minimal disturbance class compared to the light and moderate disturbance classes, but that species accumulated more rapidly in the moderate disturbance class. Cowden et al. (2014) found no significant difference in $H^{\prime}$ values among canopy disturbance severity classes for the tree layer in the same region. Differences in these findings may be the result of field sampling approaches. The contiguous plot used in our analysis captured the intra-stand heterogeneity that may have been masked by a stratified subjective sampling method used by Cowden et al. (2014). In addition, the moderate disturbance class described by Cowden et al. (2014) did not included neighborhoods of catastrophic disturbance, which were embedded in the contiguous moderate disturbance class of the 2 ha plot. Thus, patterns of increased tree diversity may only be apparent when considering neighborhoods of severe disturbance. Puettmann et al. (2009) suggested the use of spatially explicit field methods to document patterns of intra-stand heterogeneity at the neighborhood scale, as stand averages assume stand homogeneity. Species accumulation curves revealed that species richness was slightly higher in the minimal disturbance class compared to the light and moderate disturbance classes.

Diversity indices and species accumulation curves describe the composition of a stand, but such indices do not consider the spatial distribution of species within a stand. The interspersion of species (i.e. intermingling) reflects fine-scale diversity. The distribution of $M_{i}$ values by species may indicate stand compositional heterogeneity at the 
stand scale and is indicative of stand compositional heterogeneity (Graz 2004). Prior to disturbance, $M_{i}$ values were higher across all disturbance classes than post-disturbance values, consistent with studies in managed stands (Saunders and Wagner 2008). Therefore, the wind event resulted in more trees being situated near trees of the same species (i.e. more "clumps" of similar species) compared to the pre-disturbance condition. The distribution of $M_{i}$ by individual species across all disturbance classes revealed that $F$. grandifolia and $O$. virginiana had the lowest species-specific $M_{i}$, indicating that these species were more likely to occur in groups. Fagus grandifolia tends to produce root sprouts and grow in groups close to a parent tree (Jones and Raynal 1986). The low $M_{i}$ for $O$. virginiana may be a result of high densities and therefore a higher likelihood of occurring next to one another.

\subsection{Mortality related to species and size}

Larger stems were disproportionately removed by the intermediate-severity disturbance, which is consistent with other findings (Foster and Boose 1992, Peterson 2007, Rich et al. 2007, White et al. 2015). However, logistic regression analysis revealed certain taxonomic trends as well. No significant effects were present in the minimal disturbance class. However, the light disturbance class revealed $O$. virginiana and DBH were significant effects. Ostrya virginiana was inversely related with tree mortality and thus had a lower probability of being affected by the storm. Likewise, Batista and Platt (2003) documented that $O$. virginiana were not as susceptible to mortality by a hurricane. Notably, studies in adjacent stands did not note the disproportionate removal of any canopy species either (White et al. 2015). 
Although only $7 \%$ of $O$. virginiana stems were classified as decay class $1, O$. virginiana composed $21 \%$ of decay class 1 stems, the majority of which were snapped or uprooted (Fig. 7). In the light disturbance class, $71 \%$ of decay class $1 O$. virginiana stems were snapped, whereas $42 \%$ of stems in the moderate disturbance class were snapped. $O$. virginiana stems were most commonly uprooted in the moderate disturbance class (54\%). Because of the sheltered position of small O. virginiana stems, the majority of uprooted O. virginiana stems were not uprooted as a single uprooted stem, but rather were uplifted in a rootball of another uprooted stem, especially in the moderate disturbance class (i.e. the tip-up mounds contained multiple of $O$. virginiana trees). Likewise, snapped $O$. virginiana stems may have been affected by other downed stems rather than by wind disturbance alone. These hypotheses are supported by the average distances from uprooted and snapped $O$. virginiana stems to the nearest uprooted or snapped stem. The average distance of an uprooted $O$. virginiana stem to the nearest uprooted stem was 0.76 $\pm 1.06 \mathrm{~m}$, which was shorter than the average distance of a snapped $O$. virginiana stem to the nearest snapped stem $(2.02 \pm 1.29 \mathrm{~m})$ or uprooted stem $(3.04 \pm 1.69 \mathrm{~m})$.

Species-scale analyses of mortality trends across all disturbance classes revealed that C. ovata, J. virginiana, and $Q$. rubra were disproportionately removed by the storm. These species were identified based on the ratio of percent decay class 1 stems to percent of live stems. Peterson (2007) documented a wind disturbed stand with high density of $J$. virginiana and $J$. virginiana exhibited intermediate vulnerability to wind disturbance. This may be a function of wood strength or rooting habit (Peterson 2007). Juniperus virginiana stems tend to have fibrous roots when grown in rocky soils. In the light disturbance class, the majority of $J$. virginiana stems were snapped, whereas in the 
moderate disturbance class the majority of stems were uprooted. Unlike $O$. virginiana stems, the average distance of decay class $1 \mathrm{~J}$. virginiana stems to the nearest uprooted or snapped stem was $>2 \mathrm{~m}$. Thus, J. virginiana stems may have been affected by other snapped and uprooted stems, but were most likely not uplifted in a root network with another stem. A relatively large proportion of $Q$. rubra stems were in decay class 1 , similar to Cooper-Ellis et al. (1999) and Peterson (2007). Peterson (2007) noted that although $Q$. rubra has relatively flexible wood, more $Q$. rubra stems were damaged than Q. alba stems following a strong wind event.

Fagus grandifolia and N. sylvatica were disproportionately retained. A higher density and dominance of $F$. grandifolia occurred in the minimal disturbance class, which may be a result of its natural clumping from root suckers (Jones and Raynal 1986). Thus, the pre-disturbance condition may have influenced the species' retention. Peterson (2007) found that Fagus grandifolia had higher probability of mortality in larger diameter classes. However, because of the relatively high density of $F$. grandifolia stems in small diameter classes compared to large diameter classes, fewer stems were affected by the storm. Additionally, $F$. grandifolia tend to have compact crowns that are less susceptible to windthrow (Carpenter 1974, Rich et al. 2007). Nyssa sylvatica is resistant to many disturbance types, including fire, wind, flood, and drought, and may remain in the understory stratum for two centuries (Abrams 2007). Batista and Platt (2003) described $N$. sylvatica as persistent after a hurricane, which is similar to the response of $N$. sylvatica after a low severity tornado. Although N. sylvatica is resistant to various disturbances, stems of this species rarely benefit as a result of disturbance and are among the slowest growing in the eastern US (Abrams 2007). 


\section{Management implications}

Natural disturbance-based silviculture, which attempts to emulate the effects of a natural disturbance, is an increasingly popular management strategy, especially on public lands (Long 2009, Franklin and Johnson 2012). The purpose of natural disturbance-based silviculture is not to mimic the process of a natural disturbance, but rather to mimic the biological legacies left by the disturbance (Franklin et al. 2002). This management approach is hypothesized to maintain ecosystem function and promote resilience and native species diversity (Long 2009). The extent to which managers emulate these biological legacies is dependent upon individual management objectives and adoption of a natural disturbance-based approach does not inherently necessitate a change in desired stand conditions. Wind is the most common and perhaps the most influential disturbance in temperate forests and thus, may be used as a reference for natural disturbance basedmanagement (Runkle 1985, 1996, Fisher et al. 2013). However, to successfully implement natural disturbance-based silvicultural practices, quantitative descriptions of naturally disturbed stands are required as references of biological legacies (Seymour et al. 2002, Franklin et al. 2007).

Results from this study indicate that the intermediate-severity wind event resulted in increased intra-stand structural and compositional heterogeneity. By analyzing the spatial patterns of composition and structure, intra-stand patterns revealed that the storm decreased species interspersion, i.e. surviving stems occurred more frequently in groups of the same species, whereas stems occurred more frequently in groups of differing species prior to the disturbance. An irregular group shelterwood with reserves or group 
selection are silvicultural systems that may yield structures similar to the biological legacies left by a low severity tornado. Throughout the study area, basal area removed ranged from $8 \%$ to $45 \%$, with $22 \%$ removed on average. Thus, we recommend that standwide basal area retention remain between $40-80 \%$ when applying a treatment patterned after a natural intermediate-severity wind event, but treatments should be applied in groups. We recommend that initial group sizes range from 0.01 to 0.5 ha based on our findings. Although this may homogenize neighborhoods, the structural heterogeneity at the stand scale would increase (Boyden et al. 2012). Managers may wish to vary sizes of groups openings to promote regeneration of stems of various shade tolerance (sensu Lhotka 2013). To emulate patterns of the wind event, managers would preferentially remove large stems (> $30 \mathrm{~cm} \mathrm{DBH).}$

Quercus regeneration failure has been documented in the Central Hardwood Forest Region (Abrams 1992, Lorimer 1993, Nowacki and Abrams 2008, McEwan et al. 2011). Managers that wish to maintain Quercus in stands with a pre-existing shadetolerant component in the midstory likely need to make concessions on emulating structures resulting from natural disturbance. Without such concessions, an entry patterned after a natural intermediate-severity wind event would likely accelerate succession. Shelterwood systems are most commonly used to regenerate Quercus (Loftis 1990, Stringer 2006, Schweitzer and Dey 2011), but preparatory and final harvests are typically implemented uniformly throughout a stand. To promote Quercus regeneration and more closely emulate the legacy structure left by an intermediate-severity wind disturbance compared to a two-phase shelterwood, managers may implement group selection harvests around existing patches of advanced Quercus reproduction (i.e. stems 
$\geq 1.4 \mathrm{~m}$ in height). Surrounding the gap, a midstory removal preparatory cut may be used to reduce competition of more shade tolerant species and promote growth of Quercus seedlings around the gap edge, as Quercus reproduction responds positively to edge effects of clearings (Lhotka and Stringer 2013). The diameter of initial gaps should be at minimum equal to the height of surrounding trees to achieve adequate light levels (20$50 \%$ full sunlight) for growth of Quercus reproduction (Marquis 1965, Dey 2002). In subsequent entries, managers may create new gaps or expand existing gaps. However, to increase edge effects, expanded gaps may be situated tangentially rather than concentrically in relation to the initial gap. Based on specific management objectives, managers must weigh the importance placed on timber revenue and the importance of following a close-to-nature management approach.

\section{Acknowledgements}

This project was funded through a Joint Venture Agreement between the Northern Research Station, USDA Forest Service and the University of Alabama. We thank Win Cowden, Amanda Keasberry, and Cindy Taylor for assistance in the field, the Bankhead National Forest staff for logistical support, and Megan Buchanan and Michael Steinberg for comments on prior drafts of the manuscript. We are grateful for comments provided two anonymous reviewers that greatly improved the manuscript.

\section{References}

Abrams, M.D., 1992. Fire and the development of oak. Bioscience 42, 346-353. 
Abrams, M.D., 2005. Prescribing fire in eastern oak forests: is time running out?

Northern J. Appl. Forestry 22, 190-196.

Abrams, M.D. 2007. Stories from the Blackgum, a Consummate Subordinate Tree. BioScience 57, 347-359.

Abrams, M.D., Scott, M.L., 1989. Disturbance-mediated accelerated succession in two Michigan forest types. Forest Sci. 35, 42-49.

Baddeley, A., and Turner, R. 2005. Spatstat: an R package for analyzing spatial point patterns. J. Stat. Software. 12, 1-42.

Batista, W.B. and Platt, W. J. 2003. Tree population responses to hurricane disturbance: syndromes in a south-eastern USA old-growth forest. J. Ecol. 91, 197-212.

Boyden, S., Montgomery, R., Reich, P.B., and Palik, B. 2012. Seeing the forest for the heterogeneous trees: Stand-scale resource distributions emerge from tree-scale structure. Ecol. App. 22, 1578-1588.

Braun, E.L., 1950. Eastern Deciduous Forests of North America. Blakiston, Philadelphia.

Brose, P.H., Dey, D.C., Phillips, R.J., Waldrop, T.A., 2013. A meta-analysis of the fireoak hypothesis: does prescribed burning promote oak reproduction in eastern North 
America? Forest Sci. 59, 322-334.

Canham, C.D., Papaik, M.J., Latty, E.F., 2001. Interspecific variation in susceptibility to windthrow as a function of tree size and storm severity for northern temperate tree species. Can. J. For. Res. 31, 1-10.

Carpenter, R.D. 1974. American Beech. American woods. FS220. Washington, D.C.: U.S. Forest Service.

Clatterbuck, W.K., Smalley, G.W., Turner, J.A., Travis, A., 2006. Natural History and Land Use History of Cumberland Plateau Forests in Tennessee. National Council for Air and Stream Improvement, Inc., Special Report 06-01. p. 37.

Clinton, B.D., Boring, L.R., Swank, W.T., 1993. Canopy gap characteristics and drought influence in oak forests of the Coweeta Basin. Ecology 74, 1551-1558.

Cooper-Ellis, S.M., Foster, D.R., Carlton, G., Lezberg, A., 1999. Vegetation and ecosystem response to catastrophic wind: evaluation of an experimental hurricane. Ecology 80, 2683-2696.

Cowden, M.M., Hart, J.L., Schweitzer, C.J., Dey, D.C., 2014. Effects of intermediatescale wind disturbance on composition, structure, and succession in Quercus stands: Implications for natural disturbance-based silviculture. For. Ecol. Manage. 330, 240-251. 
Dey, D., 2002. The ecological basis for oak silviculture in Eastern North America. In: McShea, W.J., Healy, W.M. (Eds.), Oak Forest Ecosystems. Forest Ecology and Management, vol. 3. Johns Hopkins University Press, Baltimore, pp. 153-168.

Di Filippo, A., Pederson, N. Baliva, M., Brunetti, M., Dinella, A., Kitamura, K., Knapp, H.D., Schirone, B. and Piovesan, G. 2015. The longevity of broadleaf deciduous trees in Northern Hemisphere temperate forests: insights from tree-ring series. Front. Ecol. Evol. 3,46: 115 .

Everham, E.M., Brokaw, N.V., 1996. Forest damage and recovery from catastrophic wind. Bot. Rev. 62, 113-185.

Fei, S., Kong, N., Steiner, K.C., Moser, W.K., Steiner, E.B., 2011. Change in oak abundance in the eastern Unites States from 1980 to 2008. For. Ecol. Manage. 262, $1370-1377$.

Fenneman, N.M., 1938. Physiography of Eastern United States. Forest Science, vol. 35. McGraw-Hill Book Company, New York, pp. 91-104.

Fischer, A., Marshall, P., Camp, A., 2013. Disturbances in deciduous temperate forest ecosystems of the northern hemisphere: their effects on both recent and future forest development. Biodivers. Conserv. 22, 1863-1893. 
Foster, D.R., Boose, E.R., 1992. Patterns of forest damage resulting from catastrophic wind in central New England, USA. J. Ecol. 80, 79-98.

Foster, D.R., Motzkin, G., Slater, B., 1998. Land-use history as long-term broad-scale disturbance: regional forest dynamics in central New England. Ecosystems 1, 96-119.

Franklin, J.F., Spies, T.A., Van Pelt, R., Carey, A.B., Thornburgh, D.A., Berg, D.R., Lindenmayer, D.B., Harmon, M.E., Keeton, W.S., Shaw, D.C., Bible, K., Chen, J. 2002. Disturbances and structural development of natural forest ecosystems with silvicultural implications, using Douglas-fir forests as an example For. Eco. Manage. 155, 399-423.

Franklin, J.F., Mitchell, R.J., Palik, B.J., 2007. Natural disturbance and stand development principles for ecological forestry. USDA Forest Service General Technical Report NRS 19. USDA Forest Service Northern Experiment Station, Newton Square, PA.

Franklin, J.F. and Johnson, K.N. 2012. A restoration framework for federal forests in the Pacific Northwest. J. For. 110, 429-439.

Fraver, S., Wagner, R.G., Day, M., 2002. Dynamics of coarse woody debris following gap harvesting in the Acadian forest of central Maine, USA. Can. J. For. Res. 32, 20942105. 
Frelich, L.E., Lorimer, C.G., 1991. A simulation of landscape-level stand dynamics in the northern hardwood region. J. Ecol. 79, 223-233.

Frelich, L.E., Reich, P.B., Sugita, S., Davis, M.B., Friedman, S.K. 1998. Neighborhood effects in forests: Implications for within stand patch structure and management. J. Ecol. $86,149162$.

Gini, C. 1912. Variabilità e mutuabilità. Repreinted. In Memoriie di Metodologica Statistica. 1955. Pizetti, E. and Salvemini, T. (ed.). Libreria Eredi Virgilio Veschi, pp. 211-382.

Gotelli, N.J., Colwell, R.K., 2001. Quantifying biodiversity: procedures and pitfalls in the measurement and comparison of species richness. Ecol. Lett. 4, 379-391.

Graz, F.P. 2004. The behavior of the species mingling index $M_{s p}$ in relation to species dominance and dispersion. Eur. J. Forest Res. 123, 8792.

Griffith, G.E., Omernik, J.M., Comstock, J.A., Lawrence, S., Martin, G., Goddard, A., Hulcher, V.J., \& Foster, T. 2001. Ecoregions of Alabama and Georgia (color poster with map, descriptive text, summary tables, and photographs; map scale 1:1,7000,000). US Geological Survey, Reston, Virginia. 
Hanson, J.J., Lorimer, C.G., 2007. Forest structure and light regimes following moderate severity wind storms: implications for multi-cohort management. Ecol. Appl. 17, 13251340.

Hart, J.L., Grissino-Mayer, H.D., 2009. Gap-scale disturbance processes in secondary hardwood stands on the Cumberland Plateau, Tennessee, USA. Plant Ecol. 201, 131-146.

Hart, J.L., Clark, S.L., Torreano, S.J., Buchanan, M.L., 2012. Composition, structure, and dendroecology of an old-growth Quercus forest on the tablelands of the Cumberland Plateau, USA. For. Ecol. Manage. 266, 11-24.

Hinkle, C.R., 1989. Forest communities of the Cumberland Plateau of Tennessee. J. Tennessee Acad. Sci. 64, 123-129.

Holzmueller, E.J., Gibson, D.J., Suchecki, P.F., 2012. Accelerated succession following an intense wind storm in an oak-dominated forest. For. Ecol. Manage. 279, 141- 46.

Hosmer, D.W., Lemeshow, S., 2000. Applied Logistic Regression, 2nd ed. John Wiley \& Sons, New York.

Janowiak, M.K., Nagel, L.M. and Webster, C.R. 2008 Spatial scale and stand structure in northern hardwood forests: implications for quantifying diameter distributions. For. Sci. $54,497-506$. 
Johnson, P.S., Shifley, S.R., Rogers, R., 2009. The Ecology and Silviculture of Oaks, second ed. CAB International, Cambridge, Massachusetts, USA.

Jones, R.T., Raynal, D.J., 1986. Spatial distribution and development of root sprouts in Fagus grandifolia (Fagaceae). Am. J. Bot. 73, 1723-1731.

Keasberry A.M., Hart, J.L., Dey, D.C., and Schweitzer, C.J.. 2016. Spatial patterns of irradiance and advanced reproduction along a canopy disturbance severity gradient in an upland hardwood stand. Forests 7, 73.

Keyser, T.L., Loftis, D.L., 2012. Long-term effects of single-tree selection on structure and composition in upland hardwood forests of the southern Appalachian Mountains. Forestry.

Kint, V.,Van Meirvenne, M., Nachtergale, L., Geudens, G., and Lust, N. 2003. Spatial methods for quantifying forest stand structure development: A comparison between nearest-neighbor indices and variogram analysis. For. Sci. 49, 36-49.

Kwit, C. and Platt, W.J. 2003 Disturbance history influence regeneration of non-pioneer understory trees. Ecology 84, 2527-2581.

Leak, W.B. 1996 Long-term structural change in uneven-aged northern hardwoods. For. Sci. 42, 160-165. 
Lexerød, N and Eid, T. 2006. An evaluation of different diameter diversity indices based on criteria related to forest management planning. For. Eco. Manage. 222, 17-28.

Lhotka, J.M. 2013. Effect of gap size on mid-rotation stand structure and species composition in a naturally regenerated mixed broadleaf forest. New Forest 44, 311-325.

Lhotka, J.M. and Stringer, J.W. 2013. Forest edge effects onQuercus reproduction within naturally regenerated mixed broadleaf stands. Can. J. For. Res. 43, 911-918.

Loftis, D.L., 1990. A shelterwood method for regenerating red oak in the Southern Appalachians. Forest Sci. 36, 917-929.

Long, J.N., 2009. Emulating natural disturbance regimes as a basis for forest management: a North American view. For. Ecol. Manage. 257, 1868-1873.

Lorimer, C.G., 1980. Age structure and disturbance history of a Southern Appalachian virgin forest. Ecology 61, 1169-1184.

Lorimer, C.G., 1984. Development of the red maple understory in northeastern oak forests. Forest Sci. 30, 3-22. 
Lorimer, C.G., 1989. Relative effects of small and large disturbances on temperate hardwood forest structure. Ecology 70, 565-567.

Lorimer, C.G., 1993. Causes of the oak regeneration problem. USDA Forest Service General Technical Report, SE-84.

Lorimer, C.G., 2001. Historical and ecological roles of disturbance in eastern North American forests: 9000 years of change. Wildl. Soc. Bull. 29, 425-439.

Marquis, DA, 1965. Controlling light in small clearcuttings. USDA Forest Service Research Paper, NE-39.

McEwan, R.W., Dyer, J.M., Pederson, N., 2011. Multiple interacting ecosystem drivers: toward and encompassing hypothesis of oak forest dynamics across eastern North America. Ecography 34, 234-256.

Menard, S., 1995. Applied Logistic Regression Analysis. Sage Publications, Thousand Oaks, CA.

Mitchell, S.J. 2013. Wind as a natural disturbance agent in forests: a synthesis. Forestry $86,147157$.

National Weather Service (NWS), Birmingham, AL Weather Forecast Office, 2011, 
<http://www.srh.noaa.gov/bmx/?n=event_04202011>.

Nowacki, G.J., Abrams, M.D., 1997. Radial-growth averaging criteria for reconstructing disturbance histories from presettlement-origin oaks. Ecol. Monogr. 67, 225-249.

Nowacki, G.J., Abrams, M.D., 2008. The demise of fire and “mesophication'” of forests in the eastern United States. Bioscience 58, 123-138.

Nyland, R.D., 2002. Silviculture: Concepts and Applications. Waveland Press Inc., Long Grove, Illinois.

Oksanen, J., Blanchet, F.G., Friendly, M., Kindt, R., Legendre, P., McGlinn, D., Minchin, P.R., O'Hara, R.B., Simpson, G.L., Solymos, P., Henry, M., Stevens, H., Szoecs, E., Wagner, H., 2016. vegan: Community Ecology Package. R package version 2.4-0. https://CRAN.R-project.org/package=vegan

Oliver, C.D., Larson, B.C., 1996. Forest Stand Dynamics. John Wiley and Sons, New York.

Parker, R.P., Hart, J.L. 2014. Patterns of riparian and in-stream large woody debris across a chronosequence of southern Appalachian hardwood stands. Nat. Area. J. 34, 65-78.

Pastorella, F. and Paletto A. 2013. Stand structure indices as tools to support forest 
management: An application in Trentino forests (Italy). J. For. Sci. 59, 159168.

Peterson, C.J., 2007. Consistent influence of tree diameter and species on damage in nine eastern North America tornado blowdowns. For. Ecol. Manage. 250, 96- 108.

Peterson, C.J., Rebertus, A.J., 1997. Tornado damage and initial recovery in three adjacent, lowland temperate forests in Missouri. J. Veg. Sci. 8, 559-564.

Pommerening, A. 2002. Approaches to quantifying forest structures. Forestry. 75, 306324.

Pommerening A, Stoyan D. 2006. Edge-correction needs in estimating indices of spatial forest structure. Can. J. For. Res. 36, 1723-1739

PRISM Climate Group, 2015. http://www.prism.oregonstate.edu/

Puettmann, K.J., Coates, K.D., Messier, C.C. 2009. A Critique of Silviculture: Managing for Complexity. Island Press, Washington, D.C.

Regelbrugge, J.C., Smith, D.W. 1994. Postfire tree mortality in relation to wildfire severity in mixed oak forests in the Blue Ridge of Virginia. North. J. App. For. 11, 9097.

Rentch, J.S., Fajvan, M.A., and Hicks, R.R., Jr. 2003. Oak establishment and canopy accession strategies in five old-growth stands in the central hardwood forest region. For. 
Eco. Manage. 184, 285-297.

Rich, R.L., Frelich, L.E., Reich, P.B., 2007. Windthrow mortality in the southern boreal forest: effects of species, diameter, and stand age. J. Ecol. 95, 1261-1273.

Richards, J.D., Hart, J.L., 2011. Canopy gap dynamics and development patterns in secondary Quercus stands on the Cumberland Plateau, Alabama, USA. For. Ecol. Manage. 262, 2229-2239.

Ruffner, C.M., Abrams, M.D., 1998. Relating land-use history and climate to the dendroecology of a 326-year-old Quercus prinus talus slope forest. Can. J. For. Res. 28, $347-358$.

Runkle, J.R., 1982. Patterns of disturbance in some old-growth mesic forests of eastern North America. Ecology 63, 1533-1546.

Runkle, J.R., 1985. Disturbance regimes in temperate forests. In: Pickett, S.T.A., White, P.S. (Eds.), The Ecology of Natural Disturbance and Patch Dynamics. Academic Press, San Diego, California.

Runkle, J.R., 1996. Central Mesophytic Forests. In: Davis, M.B. (Ed.), Eastern OldGrowth Forests: Prospects for Rediscovery and Recovery. Island Press, Washington, D.C., pp. 161-177. 
Saunders, M.R., Wagner, R.G. 2008. Long-term spatial and structural dynamics in Acadian mixedwood stands managed under various silvicultural systems. Can. J. For. Res. 38, 498-517.

Schweitzer, C.J., Dey, D.C., 2011. Forest structure, composition, and tree diversity response to a gradient of regeneration harvests in the mid-Cumberland Plateau escarpment region, USA. For. Ecol. Manage. 262, 1729-1741.

Seymour, R.S., White, A.S., DeMaynadier, P.G., 2002. Natural disturbance regimes in northeastern North America - evaluating silvicultural systems using natural scales and frequencies. For. Ecol. Manage. 155, 357-367.

Smalley, G.W. 1979. Classification and evaluation for forest sites on the southern Cumberland Plateau. USDA, Forest Service, Southern Forest Experiment Station, GTR SO-23, New Orleans, LA.

Stringer, J. 2006. Oak shelterwood: a technique to improve oak regeneration. Southern Regional Extension Forestry Publication SREF-FM-005. USDA, Forest Service, Southern Region State and Private Forestry.

Stueve, K.M., Perry, C.H., Nelson, M.D., Healey, S.P., Hill, A.D., Moisen, G.G., Cohen, W.B., Gormanson, D.D., Huang, C., 2011. Ecological importance of intermediate 
windstorms rivals large, infrequent disturbances in the northern Great Lakes. Ecosphere $2,1-21$.

Szabo, M.W., Osborne, E.W., \& Neathery, T.L. 1988. Geologic Map of Alabama, Geological Survey of Alabama Special Map 220, scale 1:250,000.

Thornthwaite, C.W. 1948. An approach toward rational classification of climate. Geographical Review 38: 55-94.

Trexler, J.C., Travis, J., 1993. Nontraditional regression analyses. Ecology 74, 16291637.

USDA SCS (United Stated Department of Agriculture, Soil Conservation Service). 1959. Soil Survey: Lawrence County, AL. Series 1949, No. 10.

Weiner, J. and Solbrig, O.T. 1984. The meaning and measurement of size hierarchies in plant populations. Oecologia 61, 334336.

White, P.S., Jentsch, A., 2001. The search for generality in studies of disturbance and ecosystem dynamics. Progr. Bot. 62, 399-450.

White, P.S., MacKenzie, M.D., Busing, R.T., 1985. Natural disturbance and gap-phase dynamics in southern Appalachian Highlands spruce-fir forests. Can. J. For. Res. 15, $233-240$. 
White, S.D., Hart, J.L., Schweitzer, C.J., Dey, D.C., 2015. Altered structural development and accelerated succession from intermediate-scale wind disturbance in Quercus stands on the Cumberland Plateau, USA. For. Ecol. Manage. 336, 52-64.

Zenner, E.K., Sagheb-Talebi, K., Akhavan, R., Peck, J.E. 2015. Integration of small-scale canopy dynamics smootes live-tree structural complexity across development stages in old-growth Oriental beech (Fagus orientalis Lipsky) forests at the multi-gap scale. For. Eco. Manage. 335, 2636.

Zhang, L., Oswald, B.P., Green, T.H. 1999. Relationships between overstory species and community classification of the Sipsey Wilderness, Alabama. For. Eco. Manage. 114, $377-383$. 


\section{List of Table and Figure captions}

\section{Table 1}

Dominance $\left(\mathrm{m}^{2} \mathrm{ha}^{-1}\right)$ and density $\left(\right.$ stems ha- $\left.{ }^{-1}\right)$ measures for all live woody stems $\geq 5 \mathrm{~cm}$ DBH in the Sipsey Wilderness, William B. Bankhead National Forest, Alabama.

\section{Table 2}

Dominance $\left(\mathrm{m}^{2} \mathrm{ha}^{-1}\right)$ and density $\left(\right.$ stems ha $\left.{ }^{-1}\right)$ measures for all decay class 1 stems $\geq 5 \mathrm{~cm}$ DBH in the Sipsey Wilderness, William B. Bankhead National Forest, Alabama

Fig. 1. Contiguous 2 ha permanent plot established perpendicular to the track of an EF1 tornado in the Sipsey Wilderness, William B. Bankhead National Forest, Alabama. Disturbance severity classes, determined by basal area removed, are indicated by shading. Points representing stems are not to scale to better illustrate spatial patterns of residual trees.

Fig. 2. Density ( $\left(\mathrm{stems} \mathrm{ha}^{-1}\right.$ ) for stems $\geq 5 \mathrm{~cm} \mathrm{DBH}$ by $5 \mathrm{~cm}$ diameter size class bins and taxonomic group across three disturbance severity classes in Sipsey Wilderness, William B. Bankhead National Forest, Alabama. Black bars indicate density of live stems; white bars indicate density of decay class 1 stems. $G C=$ Gini coefficient. Because of low sample size for $F$. grandifolia in the moderate disturbance class, we only calculated the $G C$ for all Acer-Fagus stems.

Fig. 3. Density (stems $\mathrm{ha}^{-1}$ ) for $O$. virginiana stems $\geq 5 \mathrm{~cm} \mathrm{DBH}$ in $1 \mathrm{~cm}$ diameter size class bins across three disturbance severity classes in Sipsey Wilderness, William B. Bankhead National Forest, Alabama and map of a 2 ha contiguous plot. Shading on map corresponds to disturbance classes based on basal area removed by the storm. Points representing stems are not to scale 
Fig. 4. Species accumulation curves for minimal, light, and moderate disturbance classes in a $Q$. alba stand in the Sipsey Wilderness, William B. Bankhead National Forest, Alabama.

Fig. 5. Histograms of mingling index values $\left(M_{i}\right)$ by taxomomic group. A $M_{i}$ value of 1 indicates four nearest neighbors of the focal stem are different species from the focal stem. A $M_{i}$ value of 0 indicates the four nearest neighbors are the same species as the focal stem.

Fig. 6. Observed percentages of decay class 1 stems in $10 \mathrm{~cm}$ diameter size class bins in a Q. alba stand in the Sipsey Wilderness, William B. Bankhead National Forest, Alabama. Percentages are divided by taxonomic group within each diameter bin. Lines are logistic regression equations for predicted stem mortality by disturbance severity class.

Fig. 7. Density (stems ha ${ }^{-1}$ ) of decay class 1 stems by mode of death (snag, snapped stem, uprooted stem) across three disturbance severity classes on the Sipsey Wilderness, William B. Bankhead National Forest, Alabama. Stems are divided by taxonomic group. 
Dominance (m2 ha-1)

\begin{tabular}{|c|c|c|c|}
\hline & Minimal & Light & Moderate \\
\hline Acer rubrum L. & 0.1 & 0.1 & - \\
\hline Acer saccharum Marshall & 1.9 & 0.5 & 1.0 \\
\hline Carpinus caroliniana Walter & - & 0.0 & 0.1 \\
\hline Carya glabra (Mill.) Sweet & 0.6 & 0.6 & 0.4 \\
\hline Carya ovata (Mill.) K. Koch & 0.8 & 0.1 & 0.5 \\
\hline Carya tomentosa (Lam.) Nutt. & 0.2 & 0.7 & 0.4 \\
\hline Cercis canadensis L. & 0.0 & - & 0.1 \\
\hline Cornus florida L. & 0.0 & 0.3 & 0.1 \\
\hline Fagus grandifolia Ehrh. & 3.3 & 1.0 & 0.1 \\
\hline Fraxinus americana L. & 0.4 & 0.3 & 0.8 \\
\hline Fraxinus pennsylvanica Marshall & 0.0 & 0.0 & 0.1 \\
\hline Juniperus virginiana $\mathrm{L}$. & 0.1 & 0.1 & 0.0 \\
\hline Liriodendron tulipifera L. & 0.4 & 0.7 & - \\
\hline Magnolia acuminata (L.) L. & 0.4 & 0.1 & 0.0 \\
\hline Magnolia macrophylla Michx. & 0.0 & 0.1 & - \\
\hline Nyssa sylvatica Marshall & 0.3 & 0.6 & 0.1 \\
\hline Ostrya virginiana (Mill.) K. Koch & 0.6 & 1.7 & 1.6 \\
\hline Other spp.* & 0.0 & 0.1 & 0.0 \\
\hline Pinus taeda L. & 0.0 & 0.9 & - \\
\hline Quercus alba L. & 12.3 & 14.5 & 6.3 \\
\hline Quercus falcata Michx. & 1.0 & 0.4 & - \\
\hline Quercus montana Willd. & 0.7 & - & - \\
\hline Quercus muehlenbergii Engelm. & - & - & 0.6 \\
\hline Quercus rubra L. & 0.0 & - & 0.2 \\
\hline Tilia americana $\mathrm{L}$. & 0.0 & - & 0.1 \\
\hline Ulmus alata Michx. & 0.2 & 0.4 & 0.5 \\
\hline Ulmus rubra Muhl. & 0.0 & 0.0 & 0.8 \\
\hline Viburnum rufidulum Raf. & 0.0 & 0.0 & 0.1 \\
\hline Total & 23.5 & 23.2 & 13.7 \\
\hline
\end{tabular}

* Other spp. include species that had a relative importance value (i.e. sum of relative domina। opaca Aiton, Ligustrum sinense Lour., Oxydendrum arboreum (L.) DC., Prunus serotina Ehrh. 
Dominance ( $\mathrm{m} 2$ ha-1)

Relat

\begin{tabular}{|c|c|c|c|c|}
\hline & Minimal & Light & Moderate & Minimal \\
\hline Acer rubrum L. & - & 0.0 & - & - \\
\hline Acer saccharum Marshall & - & 0.2 & 0.6 & - \\
\hline Carpinus caroliniana Walter & - & 0.0 & 0.0 & - \\
\hline Carya glabra (Mill.) Sweet & 0.0 & 0.3 & 0.3 & 0.4 \\
\hline Carya ovata (Mill.) K. Koch & - & 0.2 & 2.2 & - \\
\hline Carya spp. & - & 0.4 & - & - \\
\hline Carya tomentosa (Lam.) Nutt. & 0.2 & 0.4 & 0.2 & 10.2 \\
\hline Cercis canadensis L. & - & - & 0.0 & - \\
\hline Cornus florida L. & 0.0 & 0.0 & 0.0 & 0.9 \\
\hline Fagus grandifolia Ehrh. & - & - & 0.0 & - \\
\hline Fraxinus americana $\mathrm{L}$. & - & 0.0 & 0.8 & - \\
\hline Fraxinus pennsylvanica Marshall & 0.0 & - & - & 2.0 \\
\hline Ilex opaca Aiton & - & 0.0 & - & - \\
\hline Juglans nigra L. & - & - & 0.6 & - \\
\hline Juniperus virginiana L. & 0.0 & 0.2 & 0.2 & 0.5 \\
\hline Liriodendron tulipifera L. & 0.2 & - & - & 9.8 \\
\hline Magnolia acuminata (L.) L. & 0.0 & - & 0.0 & 1.7 \\
\hline Magnolia macrophylla Michx. & 0.0 & 0.0 & - & 0.3 \\
\hline Nyssa sylvatica Marshall & - & 0.0 & - & - \\
\hline Ostrya virginiana (Mill.) K. Koch & 0.0 & 0.0 & 0.6 & 0.4 \\
\hline Pinus echinata Mill. & - & 0.4 & - & - \\
\hline Prunus serotina Ehrh. & 0.0 & - & - & 2.0 \\
\hline Quercus alba L. & 1.5 & 2.8 & 3.5 & 71.8 \\
\hline Quercus rubra L. & - & 0.2 & 1.4 & - \\
\hline Tilia americana L. & - & - & 0.0 & - \\
\hline Ulmus alata Michx. & - & - & 0.2 & - \\
\hline Ulmus rubra Muhl. & - & - & 0.4 & - \\
\hline Total & 2.1 & 5.1 & 11.0 & 100.0 \\
\hline
\end{tabular}


Figure 1
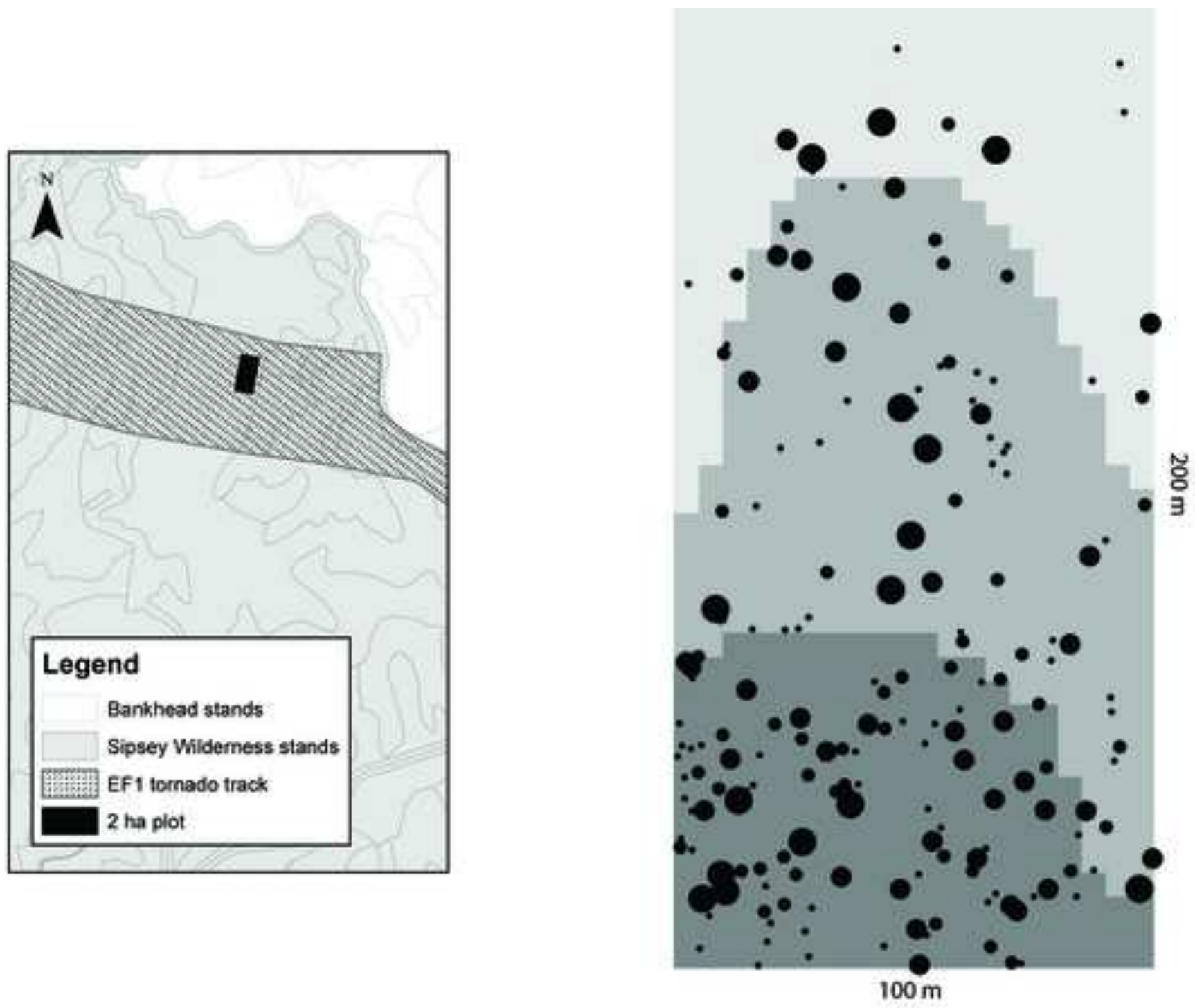

Legend

Decay class 1 stems

$\mathrm{DBH}(\mathrm{cm})$

- 5-15

- $15-30$

Minimal disturbance class

- $30-50$

Light disturbance class

- $50-75$

Moderate disturbance class. 


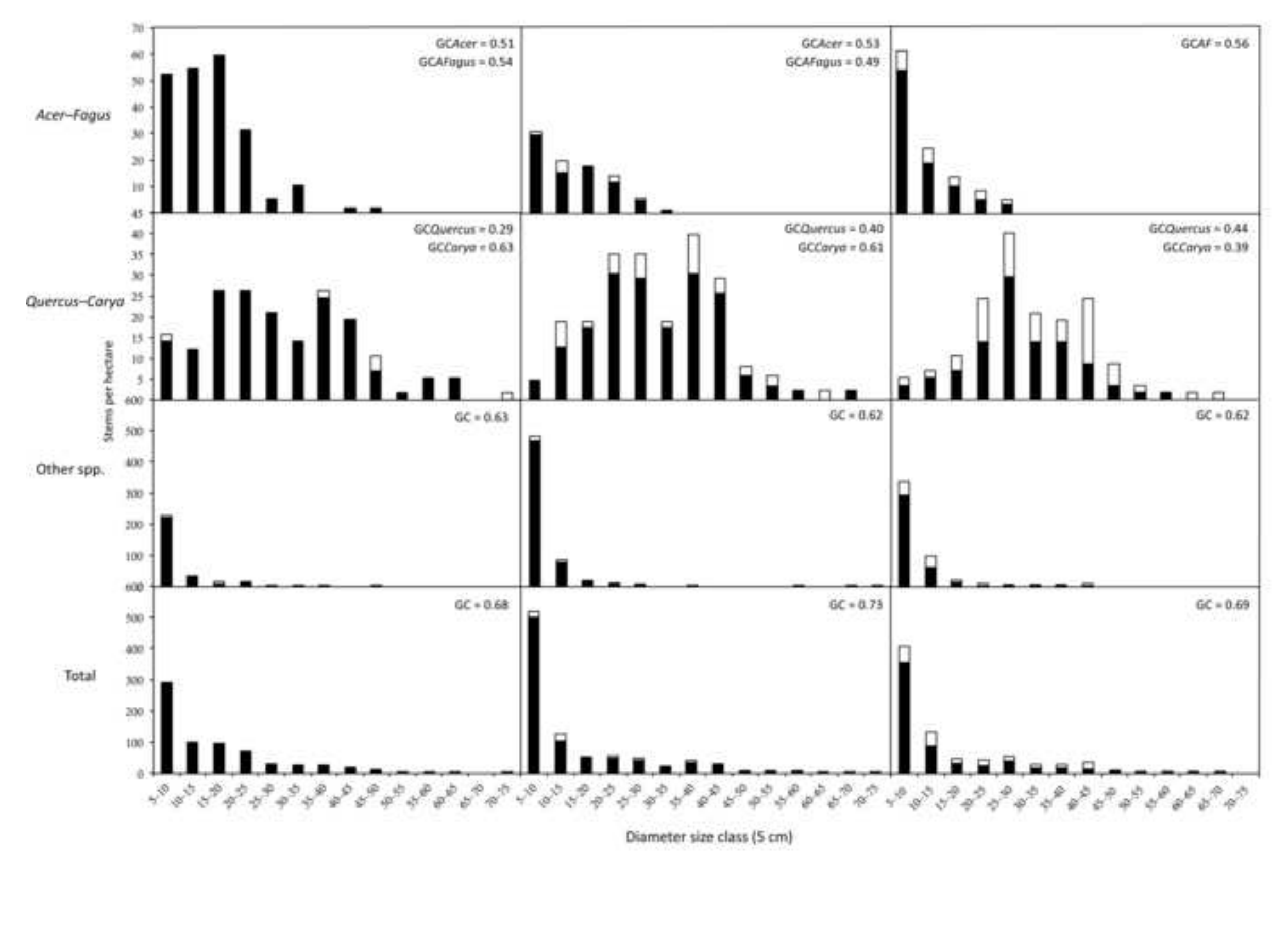

Diameter size class $(5 \mathrm{~cm}$ )

Figure 2

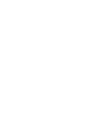

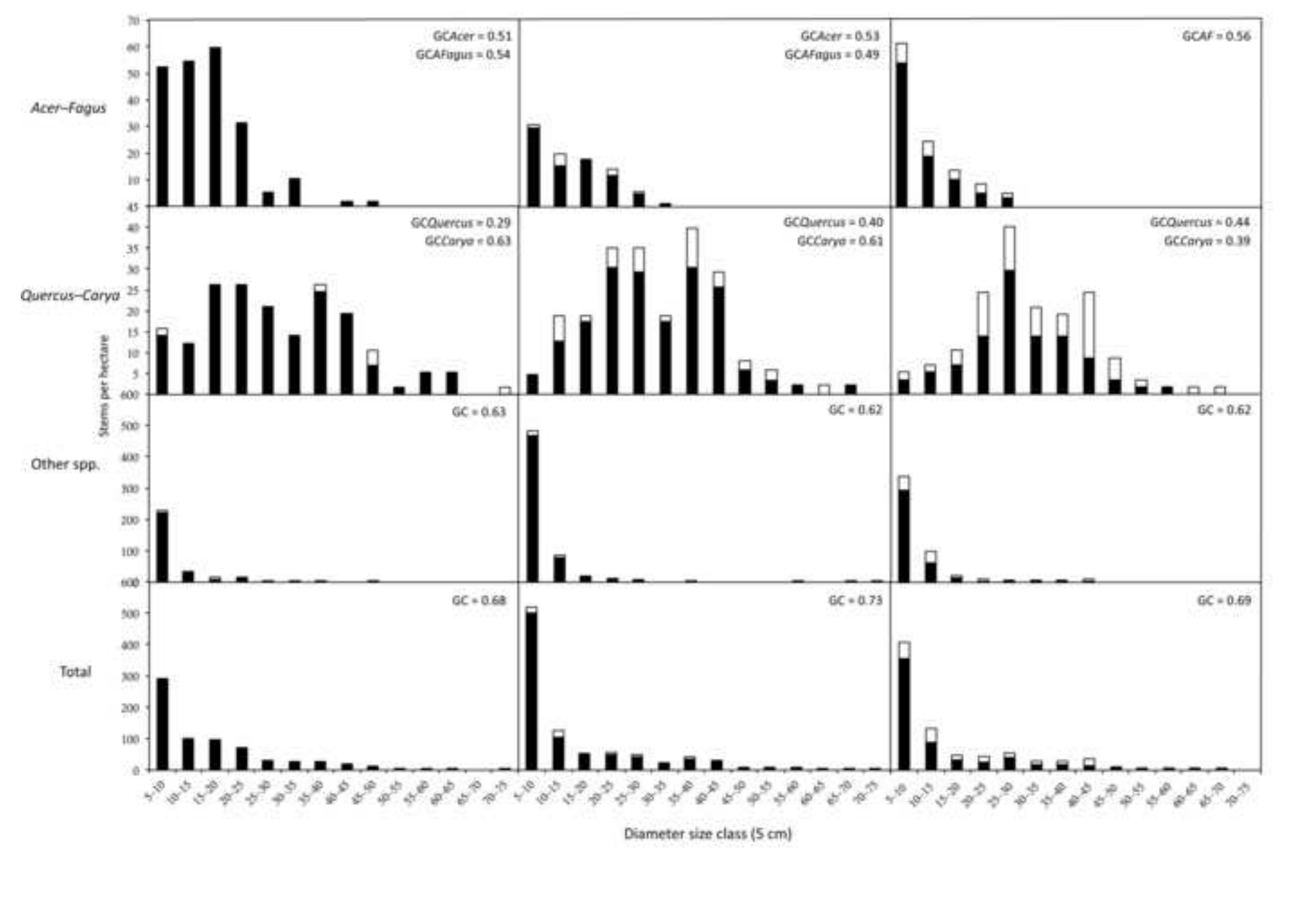

.

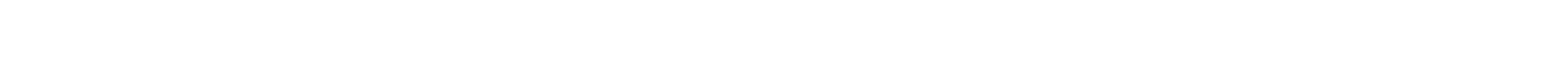

.

(n)


Figure 3
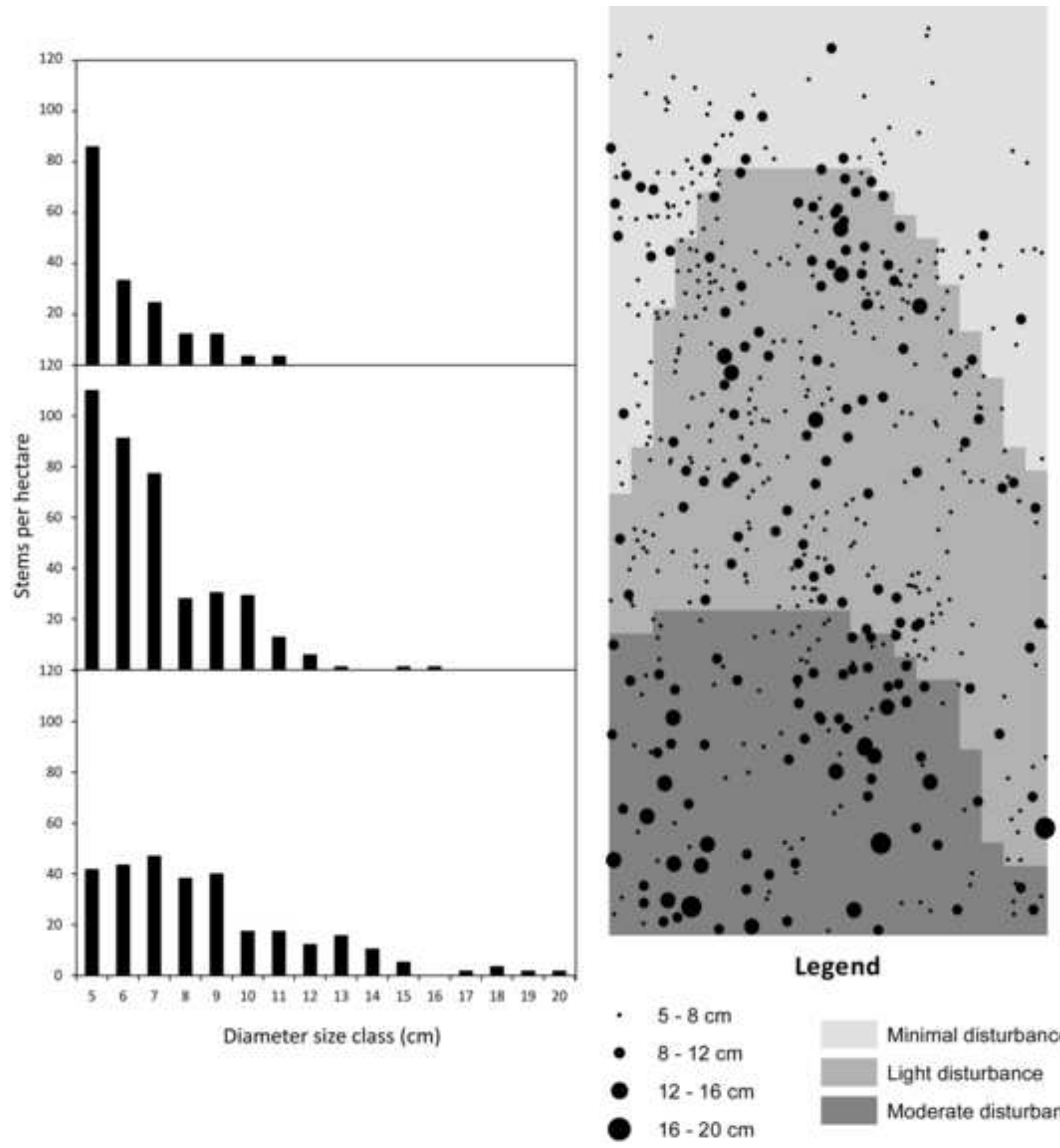

Minimal disturbance

Light disturbance

Moderate disturbance 


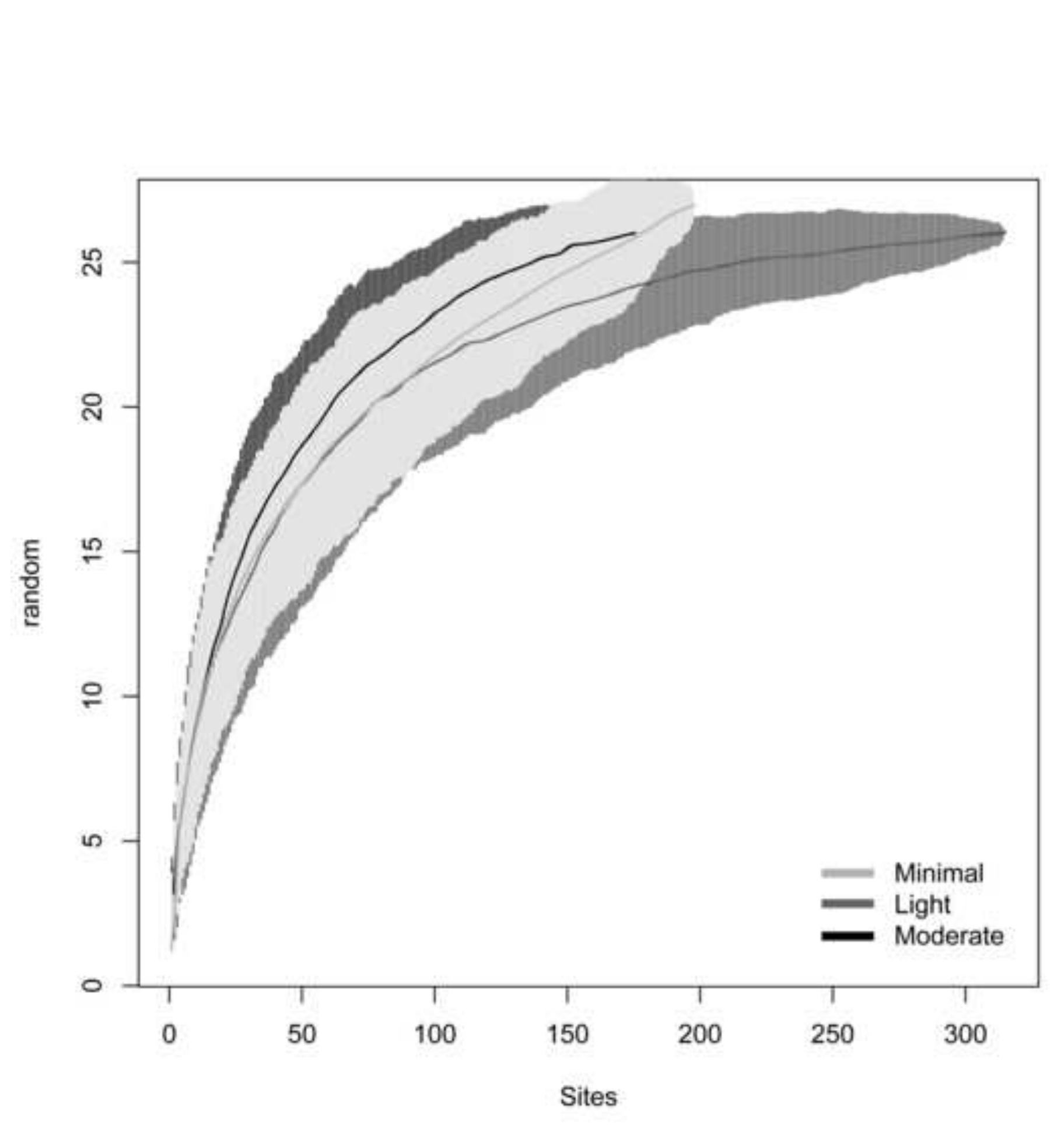

Figure 4

Figure 4

.
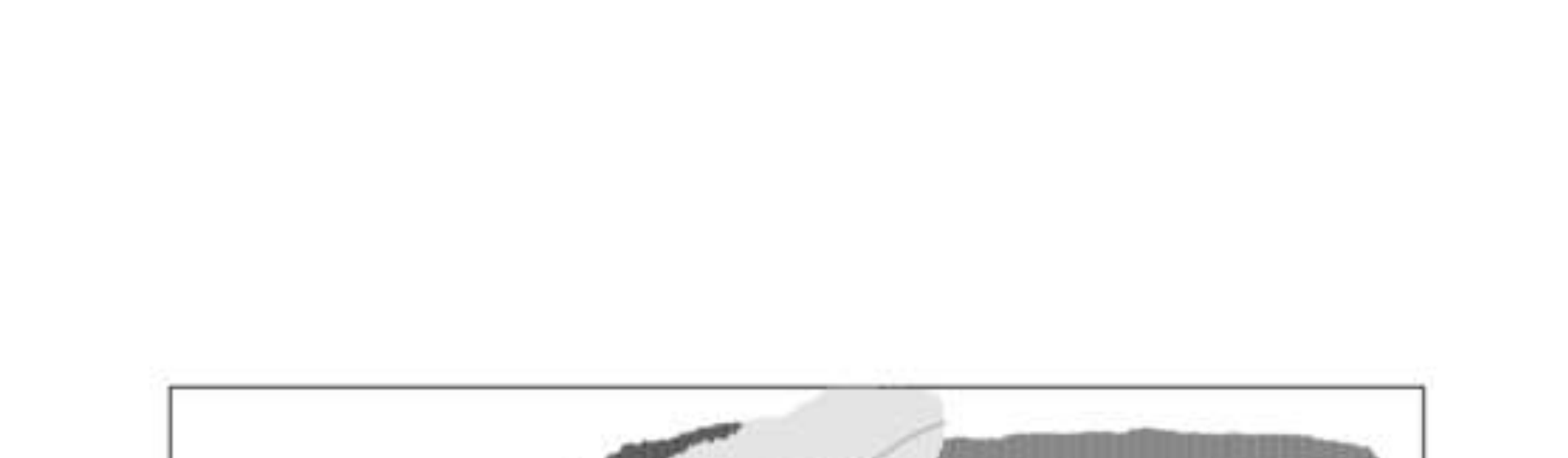


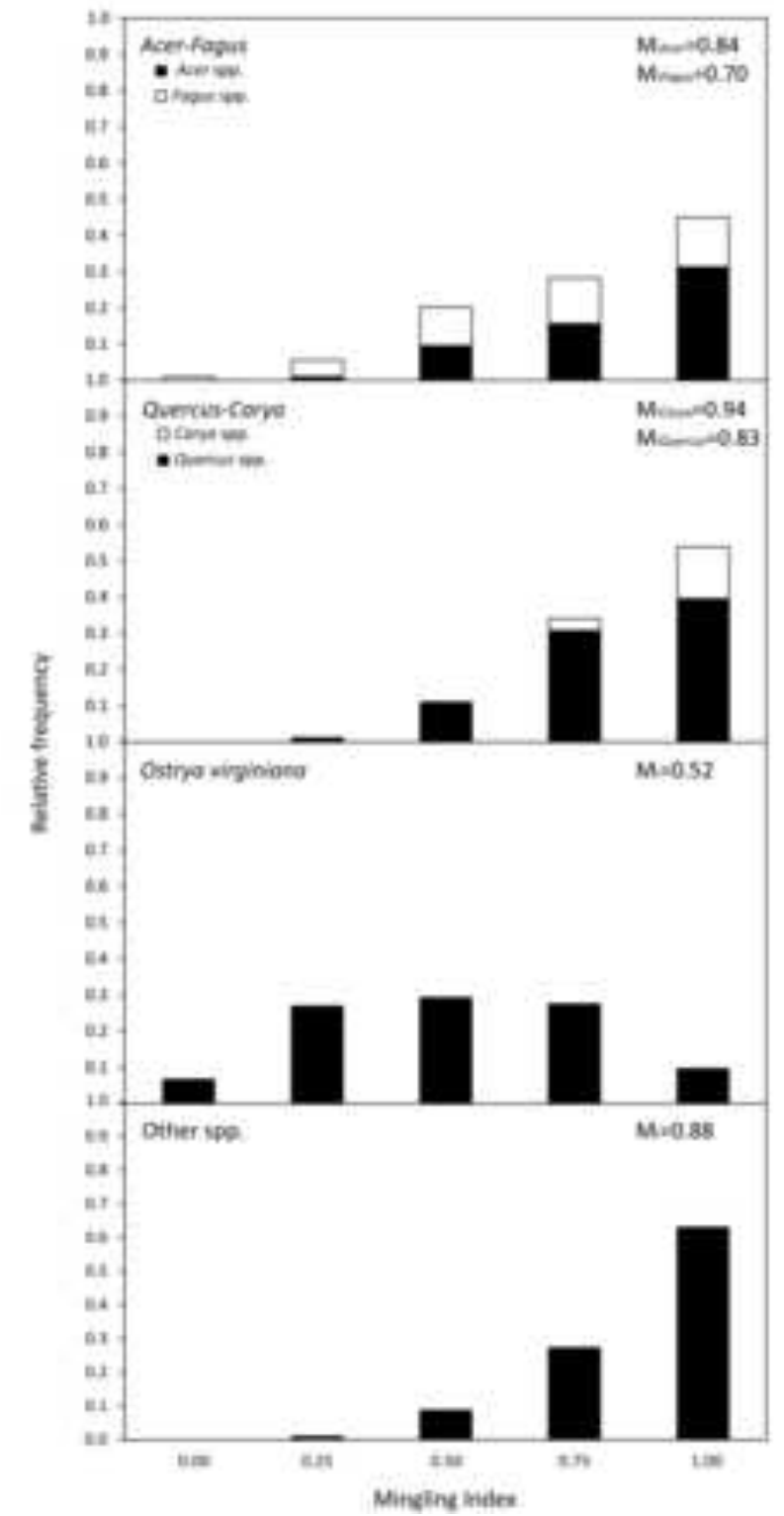




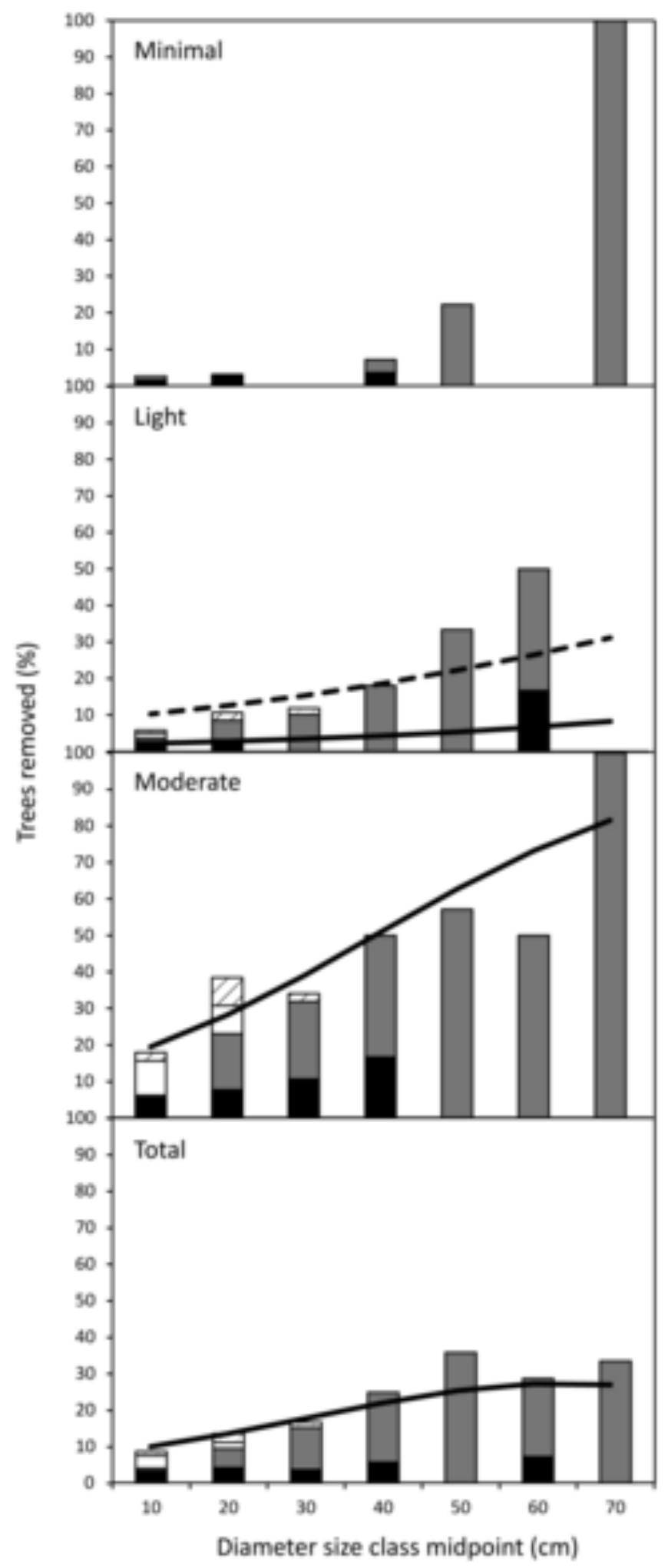

$\square$ Acer-fogus
$\square$ o. virginiano
$\square$ Cuercus-Caryo
$\square$ Oether ipp.




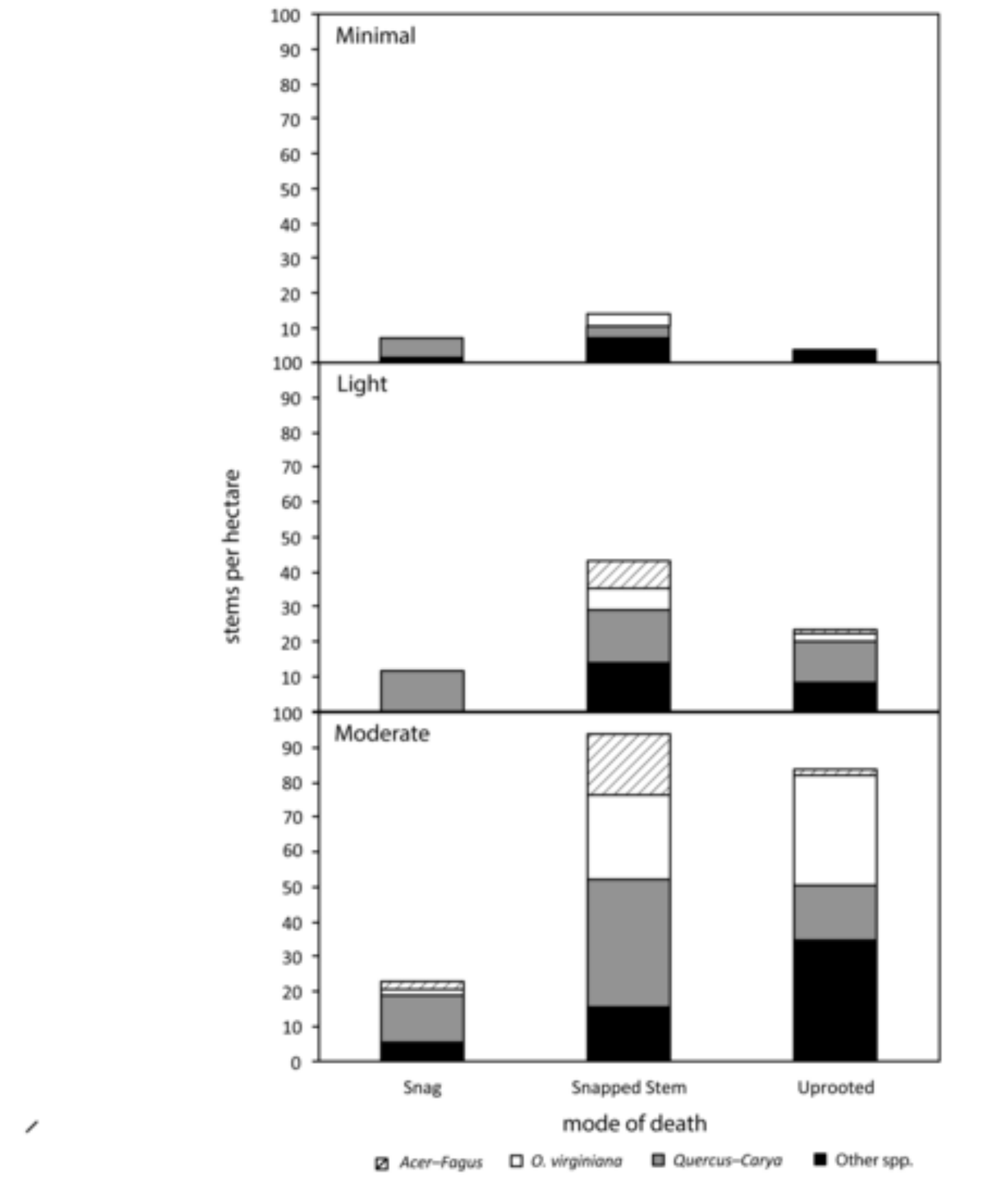

Figure 7

Figure 7

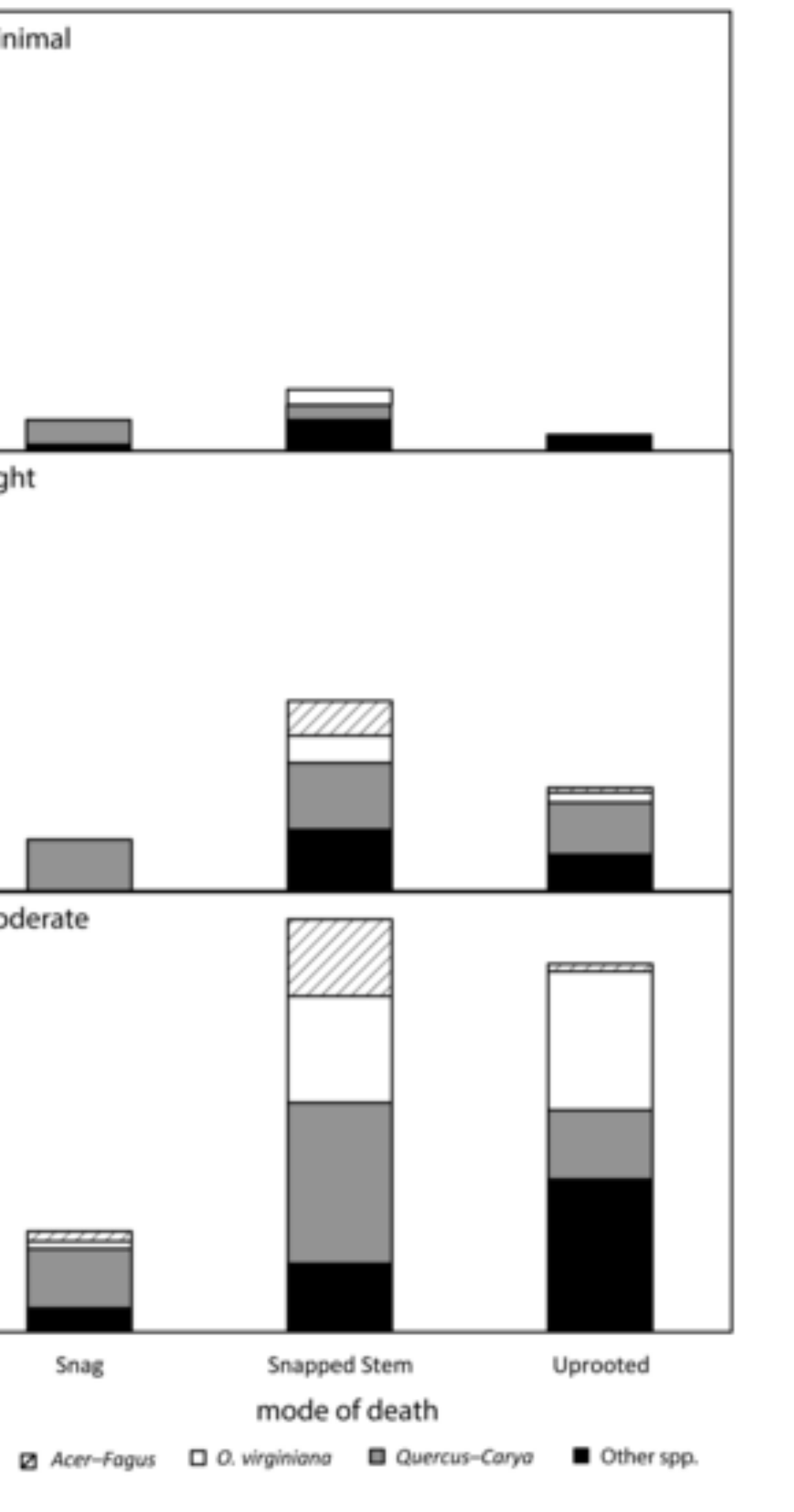

